ORIGINAL ARTICLE / ARTIGO ORIGINAL

\title{
Demographic, socioeconomic and lifestyle factors associated with sugar-sweetened beverage intake: a population-based study
}

\author{
Fatores demográficos, socioeconômicos e de estilo de vida associados \\ ao consumo de bebidas açcaradas: um estudo de base populacional
}

\author{
Amanda Silva Fontes' (D), Ana Carolina Pallottini' (D), Diva Aliete dos Santos Vieirall (D), \\ Mariane de Mello Fontanelli' (D), Dirce Maria Marchioni' (D), Chester Luiz Galvão Cesar"II (D), \\ Maria Cecilia Goi Porto Alvesiv (D), Moisés Goldbaumv (D), Regina Mara Fisberg' (D)
}

\begin{abstract}
Introduction: The intake of sugar-sweetened beverages (SSB) varies according to the characteristics of the population. Objective: To investigate the SSB intake and demographic, socioeconomic and lifestyle factors associated with its consumption in adolescents, adults, and older adults in São Paulo. Methods: Data were drawn from the Health Survey of São Paulo, a cross-sectional population-based study including 1,662 individuals aged 12 years or more. SSB were classified into six groups: sugar-sweetened sodas, sweetened coffee and tea, sweetened milk and dairy products, sweetened fruit juice, sweetened fruit drink, and total SSB. The association of each group with demographic, socioeconomic and lifestyle variables was assessed using linear regression models. Results: The mean SSB intake was $668.4 \mathrm{~mL}$ in adolescents, $502.6 \mathrm{~mL}$ in adults, and $358.2 \mathrm{~mL}$ in elderly adults. Sodas and sweetened coffee and tea represented had the greatest contribution to energy intake. SSB consumption was lower among female sex and higher among overweight adolescents, among sufficiently active adults, and among lower household per capita income older adults. Consumption of SSB was high, particularly among adolescents. Public policies are required in order to decrease the consumption of these beverages. Conclusion: Age group, sex, household per capita income, and body mass index status were associated with SSB intake.
\end{abstract}

Keywords: Nutrition surveys. Beverages. Life style. Socioeconomic factors.

'Department of Nutrition, School of Public Health, Universidade de São Paulo - São Paulo (SP), Brazil. "Center of Biological and Health Sciences, Department of Nutrition, Universidade Federal de Sergipe - Aracaju (SE), Brazil. '"Department of Epidemiology, School of Public Health, Universidade de São Paulo - São Paulo (SP), Brazil.

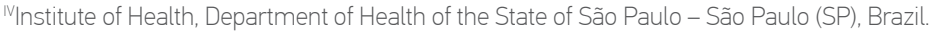

v'Department of Preventive Medicine, Medicine School, Universidade de São Paulo - São Paulo (SP), Brazil.

Corresponding author: Regina Mara Fisberg. Avenida Dr. Arnaldo, 715, Cerqueira Cesar, CEP: 01246-904, São Paulo, SP, Brazil. E-mail: rfisberg@usp.br

Conflict of interests: nothing to declare - Financial support: São Paulo Municipal Health Department (no grant number), the National Council for Scientific and Technological Development (grant numbers 481176/2008-0 and 473100/2009-6) and the São Paulo Research Foundation (grant number 2009/15831-0 and 2012/22113-9). 
RESUMO: Introdução: A ingestão de bebidas açucaradas varia de acordo com as características da população. Objetivos: Investigar o consumo de bebidas açucaradas e os fatores demográficos, socioeconômicos e de estilo de vida associados ao seu consumo em adolescentes, adultos e idosos residentes em São Paulo. Métodos: Foram utilizados dados do Inquérito de Saúde de São Paulo, estudo transversal de base populacional, incluindo 1.662 indivíduos com 12 anos ou mais. As bebidas açucaradas foram classificadas em seis grupos: refrigerantes, cafés e chás adoçados, leite e produtos lácteos adoçados, sucos de fruta natural adoçados, sucos de fruta artificial adoçados e bebidas açucaradas totais. A associação de cada grupo com variáveis demográficas, socioeconômicas e de estilo de vida foi determinada por meio de modelos de regressão linear. Resultados: A ingestão média de bebidas açucaradas foi $668,4 \mathrm{~mL}$ em adolescentes, 502,6 $\mathrm{mL}$ em adultos e 358,2 mL em idosos. Refrigerantes e cafés e chás adoçados foram os grupos com a maior contribuição para a ingestão energética. O consumo de bebidas açucaradas foi menor entre as mulheres e maior entre os adolescentes com excesso de peso, entre adultos suficientemente ativos e entre os idosos de menor renda familiar per capita. O consumo de bebidas açucaradas foi elevado, particularmente entre adolescentes. Políticas públicas são necessárias a fim de reduzir o consumo dessas bebidas. Conclusão: Faixa etária, sexo, renda familiar per capita e índice de massa corporal foram associadas ao consumo de bebidas açucaradas.

Palavras-chave: Inquéritos nutricionais. Bebidas. Estilo de vida. Fatores socioeconômicos.

\section{INTRODUCTION}

Intake of sugar-sweetened beverages (SSB) has been associated with the development of excess body weight and cardiometabolic diseases ${ }^{1}$. A study that evaluated global burdens of diseases associated with SSB consumption in 2010 found that 8.5 million disability-adjusted life years and 184,000 deaths worldwide were attributable to SSB intake. The majority of these burdens occurred in low- and middle-income countries, with a substantial morbidity and mortality rates in Latin America and the Caribbean².

Studies have shown that the intake of SSB varies according to the characteristics of the population ${ }^{3.5}$. Global SSB consumption in adults was estimated to be $137.2 \mathrm{~mL} /$ day in a study performed with data from 187 countries, with the highest consumption among men and younger adults. The study also demonstrated that the middle-income countries had higher SSB consumption when compared to high- or lower-income countries. The average SSB consumption in upper-middle income countries was $189.3 \mathrm{~mL} /$ day $^{6}$.

Most of the energy from SSB is from added/free sugar and there is a close alignment between SSB and sugar nutritional recommendations ${ }^{7}$. Data from a cross-sectional population-based study performed in eight Latin American countries indicated that approximately $70 \%$ of all individuals had added sugar intake above recommended levels, oscillating from $49.1 \%$ in Ecuador to $79.6 \%$ in Costa Rica. This number increased to $90 \%$ when more restrictive recommendations were applied, from $90.3 \%$ in Brazil to $97.9 \%$ in Peru ${ }^{8}$. The same study showed that added sugar intake was higher in women, decrease with advancing age, and, in general, was no different between socioeconomic levels ${ }^{8}$. 
Beverage intake corresponded to $17 \%$ of total daily energy in Brazilians aged 10 years or more in $2008-2009^{9}$. However, a downward trend in the intake of soft drinks and artificial juices in adults living in Brazilian capitals and Federal District from 2009 to 2016 was reported by the Surveillance System of Risk and Protection Factors for Chronic Diseases by Telephone Survey (VIGITEL). The reduction was especially seen in those aged between 18 and 44 years, with more than 12 years of study, with a partner, and residents of more developed regions ${ }^{10}$. Despite these significant findings, it is important to be aware of the limitations of the questionnaire used to collect dietary data in this survey, as well as the fact that the beverages investigated does not include all SSB, as addressed by the authors ${ }^{10}$.

Clustering of health behaviors have been described in the literature and may explain part of the association between SSB intake and the development of cardiometabolic diseases ${ }^{11}$. Studies indicate that a higher consumption of SSB is associated with reduced physical activity, current smoker status, increased consumption of alcoholic beverages, and lower adherence to the Mediterranean dietary pattern ${ }^{12,13}$, suggesting SSB intake may be a marker of an unhealthy lifestyle.

From this perspective, it is important to be aware of the quantity and types of SSB consumed, as well as of the characteristics associated with this consumption. The aims of the present study are to investigate SSB consumption and evaluate demographic, socioeconomic, and lifestyle factors associated with SSB consumption in adolescents, adults, and older adults living in São Paulo, Brazil.

\section{METHODOLOGY}

\section{STUDY SAMPLE}

Data for this study were obtained from the 2008 Health Survey of São Paulo (2008 HSP). This is a cross-sectional population-based study including a probabilistic sample of individuals living in permanent households, in the urban area of São Paulo.

A two-stage cluster sampling of census tracts and households was performed. Census tracts constituted the primary sampling units and households, the secondary. In the first stage, 70 census tracts were randomly selected among the 267 census tracts of the urban area of São Paulo included in the 2005 Continuous National Household Sample Survey 2005. For the second stage, 16,607 private households were randomly selected, within census tracts. Eight domains were fixed according to age and sex: children $<1$ year; children 1-11 years; male adolescents $12-19$ years; female adolescents $12-19$ years; male adults $20-59$ years; female adults $20-59$ years; older male adults $\geq 60$ years; and older female adults $\geq 60$ years.

For this study, only data from adolescents, adults, and older adults were used. The 2008 HSP sample was composed of 2,691 individuals aged 12 years or over (605 adolescents, 1,162 adults and 924 older adults). For information on food consumption data, a subsample of 900 participants was estimated (300 individuals per age group). This sample 
size was calculated to estimate proportions of 0.5 with a sample error of 0.07 at a $5 \%$ significance level and design effect of 1.5 . To compensate for possible losses, $25 \%$ more individuals were drawn. The first 24-hour dietary recall (24HR) was collected in 1,662 individuals aged 12 years or over ( 560 adolescents, 585 adults, and 517 older adults). The second 24HR was collected in 832 subjects ( 232 adolescents, 302 adults, and 298 older adults). This study used information from 1,662 individuals with demographic, socioeconomic and lifestyle information and first measure of the $24 \mathrm{HR}$, and 1,582 with complete data were included in the regression models.

The Ethics Committee of the São Paulo Municipal Health Department and the Public Health School of University of São Paulo approved the study (CAAE No. 26800414.1.0000.5421). All participants were enrolled in the study after providing free and written informed consent.

\section{DATA COLLECTING AND PROCESSING}

Between 2008 and 2009, a home visit was performed to collect demographic, socioeconomic, and lifestyle data using a structured questionnaire. This study will use the following demographic, socioeconomic, and lifestyle parameters: sex, age, self-reported skin color, level of education of the household head, household per capita income, smoking status, alcohol consumption, physical activity level, weight, and height.

For the classification of the age group (adolescents, adults and older adults), the definitions of the World Health Organization and the Brazilian Child and Adolescent Statute were considered. Self-reported skin color was classified as "white and yellow" and "black and brown". The level of education of the household head was measured in years of study and classified as $\leq$ nine years and $\geq$ ten years of study. Household per capita income was calculated using the sum of the income of all family members, divided by the number of family members, and it was classified as $\leq 1$ minimum wage and $>1$ minimum wage (R\$ 415.00 or US\$ 260.00 in 2008). Smoking status was classified as never, current, and former smoker. Individuals were classified as consumer or no consumer of alcoholic beverages.

Physical activity was collected by the long version of the International Physical Activity Questionnaire validated for the Brazilian population ${ }^{14}$. Leisure time physical activity was classified as insufficiently active or sufficiently active (physical activity practiced for at least 30 minutes daily, 5 days per week, at a moderate intensity or at least 20 minutes daily, 3 days per week, at a vigorous intensity).

Body mass index (BMI) was calculated on the basis of self-reported weight and height and classified according to the cut-off for adolescents, adults and older adults ${ }^{15-17}$. This information was previously validated in the studied population ${ }^{18}$. 


\section{DIETARY INTAKE DATA}

Food consumption data were collected using two 24HR. The median time between the two 24HR measures was 184 days. Data were collected on non-consecutive days, representing every day of the week and all seasons of the year. The first $24 \mathrm{HR}$ data were collected during the first home visit, and the second 24HR was conducted by telephone, using the Automated Multiple Pass Method ${ }^{19}$. The Nutrition Data System for Research (NDSR) software, 2007 version, was used for data collection. The main source of NDSR data is the food composition table developed by the United States Department of Agriculture, therefore, foods typed in every inquiry have nutritional value compared to the values available in national tables ${ }^{20-22}$.

The equations used to calculate the estimated energy requirements (EER) on an individual basis were obtained from the Institute of Medicine of the National Academies ${ }^{23}$. The EER is the average dietary energy intake required to preserve energy balance according to age, sex, weight and physical activity level ${ }^{23}$. In an individual with stable body weight, the dietary energy intake is compatible with the EER, therefore it is possible to estimate and account for misreporting, a common error of self-reported dietary intake ${ }^{24}$. The misreporting percentage of each individual energy needs was determined by: energy intake - EER / EER × $100^{25}$.

\section{SUGAR-SWEETENED BEVERAGES}

SSB were defined as any beverages containing a caloric sweetener, either intrinsic to the product formulation or added before consumption ${ }^{26}$. If the respondent reported adding sugar to the consumed beverage, this quantity was also taken into account. When there was no information available regarding the quantity of sugar added before beverage consumption in the $24 \mathrm{HR}$, a further $5 \mathrm{~g}$ of sugar for each $100 \mathrm{~mL}$ of beverage were considered.

All SSB cited in the $24 \mathrm{HR}$ were classified into six groups:

- sugar-sweetened sodas (soft drinks with added sugar);

- sweetened coffee and tea (e.g. coffee, coffee and milk, cappuccino and tea with sugar added);

- sweetened milk and dairy products (e.g. milk, milk with chocolate, yogurt with sugar added);

- sweetened fruit juice (natural fruit juices with sugar added before consumption);

- sweetened fruit drink (e.g. dry-mix fruit drinks, nectar and drinks beverages, sports drinks with added sugar);

- total SSB (sum of all categories). 
SSB consumed by $<5 \%$ of the population or not nutritionally similar to any group were excluded from the analysis; these included sugar sweetened alcoholic beverages, beverages with artificial sweeteners, and soy-based beverages.

The usual SSB intake was estimated using the Multiple Source method, which combines the probability and the amount of food consumed to estimate the usual intake for each individual ${ }^{27}$. To ensure the accuracy of the estimates, it is required to have two short-come measurements of dietary intake for at least $40 \%$ of the population studied ${ }^{28}$. For this study, the replication rate was $55.69 \%$.

\section{STATISTICAL ANALYSES}

The characteristics of the subjects were presented as percentages and $95 \%$ confidence interval. Intake of SSB was described according to the daily amount consumed and the proportion of total daily energy intake. The association between each SSB group and total SSB intakes, respectively, and demographic, socioeconomic, and lifestyle variables was calculated using linear regression models for each age group. All the models had the following factors as independent variables: sex, physical activity, smoking status, household per capita income, BMI, self-reported skin color, and alcohol consumption. All the models were adjusted for misreporting and were accepted after residual analysis. The inclusion of the variables was based on references, and on the univariate linear regression models $\mathrm{s}^{3-5}$. Variables not mentioned in the literature, but with the $\mathrm{p}<0.20$ were considered for inclusion on the linear multiple regression models. The inclusion process was performed from the lowest to the highest p-value. All analyses considered the complexity of the sample design by using the survey module of the STATA ${ }^{\circledR}$ (Statistics/Data Analysis, version 13.0, Texas, 115 USA).

\section{RESULTS}

The characteristics of the participants of the study are presented in Table 1. The subjects were predominantly female, self-reported white and yellow skin colored, non-smokers, and alcohol consumers. The majority of participants head of the family had 10 or more years of education and household per capita income higher than 1 minimum wage. Excess body weight was observed in $43.1 \%$ of subjects and $85.6 \%$ were insufficiently active.

Total consumption of SSB was greater among adolescents, and the most consumed beverages were sugar-sweetened sodas (Table 2). Adolescents also presented higher intake of sweetened milk and dairy products and sweetened fruit drinks. Total daily energy intake from SSB varied from 10.4 to $14.5 \%$ in older adults and adolescents, respectively. 
Table 3 shows the association between each SSB group and demographic, socioeconomic, and lifestyle variables in adolescents, adults and older adults. In adolescents, female sex participants presented lower mean intake of sugar-sweetened soda and total SSB intake

Table 1. Characteristics of the participants in the Health Survey of São Paulo 2008 according to age group. São Paulo, 2008.

\begin{tabular}{|c|c|c|c|c|c|c|c|c|}
\hline \multirow{2}{*}{ Characteristics } & \multicolumn{2}{|c|}{ Adolescents } & \multicolumn{2}{|c|}{ Adults } & \multicolumn{2}{|c|}{ Older adults } & \multicolumn{2}{|r|}{ Total } \\
\hline & $\%$ & $95 \% \mathrm{Cl}$ & $\%$ & $95 \% \mathrm{Cl}$ & $\%$ & $95 \% \mathrm{Cl}$ & $\%$ & $95 \% \mathrm{Cl}$ \\
\hline \multicolumn{9}{|l|}{ Sex } \\
\hline Male & 50.1 & $45.3-54.9$ & 46.9 & $43.3-50.6$ & 40.5 & $36.6-44.5$ & 46.5 & $43.9-49.2$ \\
\hline Female & 49.9 & $45.1-54.7$ & 53.1 & $49.5-56.7$ & 59.5 & $55.5-63.4$ & 53.5 & $50.8-56.1$ \\
\hline \multicolumn{9}{|l|}{ Skin color } \\
\hline White and yellow & 56.8 & $49.3-63.9$ & 58.3 & $52.7-63.7$ & 70.9 & $65.2-76.0$ & 59.8 & $54.7-64.8$ \\
\hline Black and brown & 43.2 & $36.1-50.7$ & 41.7 & $36.3-47.3$ & 29.1 & $24.0-34.8$ & 40.2 & $35.2-45.3$ \\
\hline \multicolumn{9}{|l|}{ Smoking status } \\
\hline Non-smoker & 93.1 & $90.7-94.9$ & 59.5 & $54.4-64.3$ & 56.6 & $51.8-61.3$ & 64.2 & $60.4-67.7$ \\
\hline Former smoker & 2.6 & $1.5-4.2$ & 15.5 & $12.3-19.5$ & 33.2 & $29.0-37.8$ & 16.0 & $13.5-19.0$ \\
\hline Current smoker & 4.3 & $2.9-6.4$ & 25.0 & $20.5-30.0$ & 10.2 & $7.4-13.7$ & 19.8 & $16.6-23.4$ \\
\hline \multicolumn{9}{|l|}{ Alcohol consumption } \\
\hline Non-consumer & 66.5 & $61.3-71.4$ & 41.8 & $38.2-45.4$ & 62.7 & $57.8-67.4$ & 48.4 & $45.3-51.5$ \\
\hline Consumer & 33.5 & $28.6-38.7$ & 58.2 & $54.6-61.8$ & 37.3 & $32.6-42.2$ & 51.6 & $48.5-54.7$ \\
\hline
\end{tabular}

Education of the head of the family

\begin{tabular}{|c|c|c|c|c|c|c|c|c|}
\hline$\leq 9$ years & 45.7 & $39.3-52.3$ & 43.4 & $36.1-51.1$ & 65.1 & $58.7-71.0$ & 46.8 & $41.0-52.7$ \\
\hline$\geq 10$ years & 54.3 & $47.7-60.7$ & 56.6 & $48.9-63.9$ & 34.9 & $29.0-41.3$ & 53.2 & $47.3-59.0$ \\
\hline \multicolumn{9}{|c|}{ Household per capita income } \\
\hline$\leq 1$ minimum wage & 60.9 & $53.6-67.7$ & 39.5 & $33.4-46.0$ & 44.7 & $37.3-52.3$ & 43.5 & $38.3-48.8$ \\
\hline$>1$ minimum wage & 39.1 & $32.3-46.4$ & 60.5 & $54.0-66.6$ & 55.3 & $47.7-62.8$ & 56.5 & $51.3-61.7$ \\
\hline \multicolumn{9}{|l|}{ Body mass index } \\
\hline Without EBW & 70.7 & $65.8-75.2$ & 52.6 & $48.1-57.0$ & 63.6 & $59.7-67.4$ & 56.9 & $53.3-60.3$ \\
\hline With EBW & 29.3 & $24.8-34.2$ & 47.4 & $43.0-51.9$ & 36.4 & $32.6-40.3$ & 43.1 & $39.7-46.7$ \\
\hline \multicolumn{9}{|l|}{ Physical activity } \\
\hline Insufficiently active & 75.1 & $69.9-79.7$ & 87.1 & $83.4-90.0$ & 89.6 & $86.5-92.1$ & 85.6 & $82.9-87.9$ \\
\hline Sufficiently active & 24.9 & $20.3-30.1$ & 12,9 & $10.0-16.6$ & 10.4 & $7.9-13.5$ & 14.4 & $12.1-17.1$ \\
\hline
\end{tabular}


when compared with male sex. Adolescents who self-reported black and brown skin color presented higher mean intake of sweetened coffee and tea. Household per capita family income of participants in this age group was negatively associated with the intake of sweetened coffee and tea and sweetened fruit drink, and positively associated with the intake of sweetened fruit juice. Adolescents with excess body weight presented higher intake of sugar-sweetened soda and total SSB when compared with subjects at the same age group without excess body weight.

In adults, female sex participants presented lower mean intake of sugar-sweetened soda, sweetened milk and dairy products and total SSB when compared with male sex. Adults who are former or current smokers presented lower intake of sweetened milk and dairy products when compared to non-smokers. Sufficiently active adults presented higher mean intake of sweetened milk and dairy products and total SSB when compared to insufficiently active ones (Table 3 ).

In older adults, female sex participants and alcohol consumers presented higher mean intake of sweetened fruit juice when compared to male sex and non-consumers, respectively. Older adults with excess body weight had higher intake of sweetened fruit drink compared to older adults without excesses body weight. Household per capita income was negatively associated with the intake of sweetened coffee and tea, sweetened fruit juices and total SSB intake (Table 3).

Table 2. Sugar-sweetened beverage intake according to amount ( $\mathrm{mL} /$ day) and proportion $(\%)$ of total daily energy intake among adolescents, adults and older adults. São Paulo, 2008.

\begin{tabular}{|c|c|c|c|c|c|c|c|c|}
\hline \multirow{2}{*}{$\begin{array}{l}\text { Beverages } \\
\text { group }\end{array}$} & \multicolumn{4}{|c|}{$\begin{array}{c}\mathrm{mL} / \mathrm{d} \\
\text { Mean } \\
\text { (standard deviation) }\end{array}$} & \multicolumn{4}{|c|}{$\begin{array}{l}\text { \% total daily energy } \\
\text { Mean } \\
\text { (standard deviation) }\end{array}$} \\
\hline & Total & Adolescents & Adults & $\begin{array}{l}\text { Older } \\
\text { adults }\end{array}$ & Total & Adolescents & Adults & $\begin{array}{l}\text { Older } \\
\text { adults }\end{array}$ \\
\hline $\begin{array}{l}\text { Sugar- } \\
\text { sweetened } \\
\text { sodas }\end{array}$ & $\begin{array}{l}163.6 \\
(172.8)\end{array}$ & $\begin{array}{l}263.9 \\
(216.3)\end{array}$ & $\begin{array}{c}157.0 \\
(164.7)\end{array}$ & $\begin{array}{l}87.3 \\
(92.8)\end{array}$ & $\begin{array}{c}3.8 \\
(3.7)\end{array}$ & $\begin{array}{c}5.3 \\
(4.1)\end{array}$ & $\begin{array}{c}3.7 \\
(3.7)\end{array}$ & $\begin{array}{l}2.6 \\
(2.6)\end{array}$ \\
\hline $\begin{array}{l}\text { Sweetened } \\
\text { coffee and tea }\end{array}$ & $\begin{array}{c}164.4 \\
(151.0)\end{array}$ & $\begin{array}{c}115.6 \\
(133.1)\end{array}$ & $\begin{array}{c}174.3 \\
(152.4)\end{array}$ & $\begin{array}{c}166.8 \\
(153.0)\end{array}$ & $\begin{array}{l}3.6 \\
(3.6)\end{array}$ & $\begin{array}{c}2.2 \\
(2.7)\end{array}$ & $\begin{array}{c}3.7 \\
(3.5)\end{array}$ & $\begin{array}{c}4.5 \\
(4.5)\end{array}$ \\
\hline $\begin{array}{l}\text { Sweetened } \\
\text { milk and dairy } \\
\text { products }\end{array}$ & $\begin{array}{c}56.2 \\
(99.9)\end{array}$ & $\begin{array}{c}101.0 \\
(129.0)\end{array}$ & $\begin{array}{l}51.1 \\
(96.0)\end{array}$ & $\begin{array}{l}32.9 \\
(61.9)\end{array}$ & $\begin{array}{l}2.6 \\
(4.3)\end{array}$ & $\begin{array}{c}4.3 \\
(5.4)\end{array}$ & $\begin{array}{c}2.4 \\
(4.2)\end{array}$ & $\begin{array}{c}1.9 \\
(3.4)\end{array}$ \\
\hline $\begin{array}{l}\text { Sweetened } \\
\text { fruit juice }\end{array}$ & $\begin{array}{c}29.8 \\
(69.1)\end{array}$ & $\begin{array}{c}43.9 \\
(104.6)\end{array}$ & $\begin{array}{c}28.8 \\
(63.0)\end{array}$ & $\begin{array}{c}19.4 \\
(43.13)\end{array}$ & $\begin{array}{l}0.61 \\
(1.3)\end{array}$ & $\begin{array}{c}0.7 \\
(1.5)\end{array}$ & $\begin{array}{c}0.6 \\
(1.2)\end{array}$ & $\begin{array}{c}0.5 \\
(1.2)\end{array}$ \\
\hline $\begin{array}{l}\text { Sweetened } \\
\text { fruit drinks }\end{array}$ & $\begin{array}{c}87.3 \\
(116.8)\end{array}$ & $\begin{array}{c}123.4 \\
(138.0)\end{array}$ & $\begin{array}{c}87.3 \\
(116.2)\end{array}$ & $\begin{array}{c}47.6 \\
(75.0)\end{array}$ & $\begin{array}{l}1.1 \\
(1.6)\end{array}$ & $\begin{array}{c}1.5 \\
(2.0)\end{array}$ & $\begin{array}{c}1.1 \\
(1.6)\end{array}$ & $\begin{array}{c}0.7 \\
(1.1)\end{array}$ \\
\hline $\begin{array}{l}\text { Total sugar- } \\
\text { sweetened } \\
\text { beverages }\end{array}$ & $\begin{array}{l}507.7 \\
(262.1)\end{array}$ & $\begin{array}{l}668.4 \\
(280.2)\end{array}$ & $\begin{array}{c}502.6 \\
(250.0)\end{array}$ & $\begin{array}{c}358.2 \\
(198.2)\end{array}$ & $\begin{array}{l}11.9 \\
(6.3)\end{array}$ & $\begin{array}{l}14.5 \\
(6.3)\end{array}$ & $\begin{array}{l}11.7 \\
(6.2)\end{array}$ & $\begin{array}{l}10.4 \\
(6.4)\end{array}$ \\
\hline
\end{tabular}


Table 3. Demographic, socioeconomic, and lifestyle variables associated with sugar-sweetened beverage intake in adolescents, adults and older adults. São Paulo, 2008.

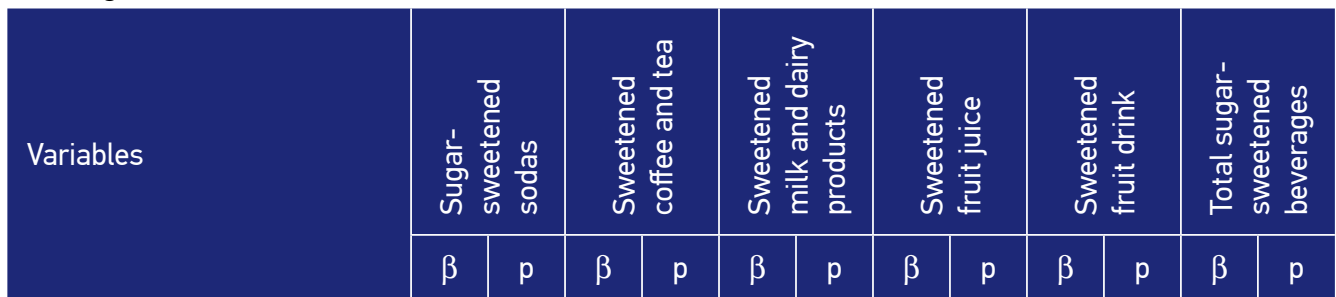

Adolescents

Sex (ref. male)

Female

$-75.90 .001-21.6 \quad 0.100-11.40 .436 \quad 12.0 \quad 0.169-22.90 .097-141.10 .000$

Skin color (ref. white and yellow)

Black and brown

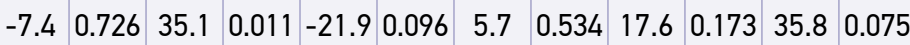

Smoking status (ref. non-smoker)

Former smoker

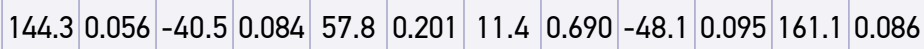

Current smoker

$\begin{array}{lllllllllllll}6.4 & 0.878 & 38.3 & 0.117 & -10.6 & 0.628 & 5.62 & 0.833 & -13.7 & 0.548 & 16.2 & 0.717\end{array}$

Alcohol consumption (ref. non-consumer)

\begin{tabular}{l|l|l|l|l|l|l|l|l|l|l|l|l}
\hline Consumer & -13.4 & 0.468 & 11.6 & 0.325 & -12.8 & 0.274 & 4.4 & 0.630 & 8.9 & 0.480 & -12.4 & 0.640 \\
\hline $\begin{array}{l}\text { Household per capita } \\
\text { income (US\$ per month) }\end{array}$ & 0.4 & 0.792 & -1.3 & 0.019 & -0.0 & 0.945 & 3.2 & 0.027 & -1.9 & 0.000 & 1.2 & 0.343 \\
\hline
\end{tabular}

Body Mass Index (ref. without excess body weight)

With excess body

weight

$\begin{array}{lllllllllllll}62.7 & 0.006 & -11.7 & 0.461 & 22.3 & 0.155 & 17.8 & 0.148 & -6.9 & 0.743 & 103.2 & 0.001\end{array}$

Physical activity (ref. Insufficiently active)

\begin{tabular}{l|l|l|l|l|l|l|l|l|l|l|l|l}
\hline \multicolumn{1}{c|}{ Sufficiently active } & 40.8 & 0.067 & -12.0 & 0.378 & 21.8 & 0.161 & -14.1 & 0.072 & 5.1 & 0.692 & 41.5 & 0.098 \\
\hline Adults & \\
\hline $\begin{array}{l}\text { Sex (ref. male) } \\
\quad \text { Female }\end{array}$ & -33.3 & 0.031 & 5.2 & 0.673 & -9.7 & 0.354 & 1.8 & 0.770 & -14.7 & 0.153 & -61.2 & 0.014 \\
\hline
\end{tabular}

Skin color (ref. white and yellow)

\begin{tabular}{|c|c|c|c|c|c|c|c|c|c|c|c|}
\hline Black and brown & 29.1 & 0.086 & 0.95 & 0.945 & -18.20 .050 & 1.4 & 0.843 & 15.8 & 0.130 & 30.4 & 0.096 \\
\hline \multicolumn{12}{|c|}{ Smoking status (ref. non-smoker) } \\
\hline Former smoker & -12.2 & 0.507 & 13.1 & 0.287 & -25.30 .025 & 1.5 & 0.836 & -16.8 & 0.185 & -34.3 & 30.259 \\
\hline Current smoker & 15.2 & 0.412 & 26.3 & 0.125 & -25.10 .037 & -5.9 & 0.280 & -19.6 & 0.238 & -9.0 & 0.757 \\
\hline
\end{tabular}

Continue... 
Table 3. Continuation.

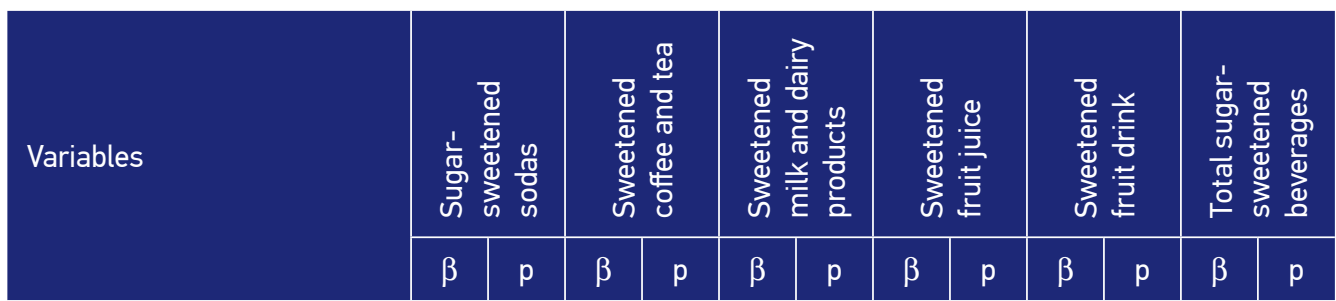

Alcohol consumption (ref. non-consumer)

\begin{tabular}{|c|c|c|c|c|c|c|c|c|c|c|c|c|}
\hline Consumer & -5.3 & 0.060 & -9.6 & 0.518 & 9.4 & 0.365 & -0.8 & 0.890 & 9.0 & 0.428 & 14.7 & 0.599 \\
\hline $\begin{array}{l}\text { Household per capita } \\
\text { income (US\$ per month) }\end{array}$ & -0.6 & 0.413 & -1.6 & 0.102 & 0.6 & 0.265 & -0.3 & 0.092 & 0.1 & 0.905 & -1.7 & 0.171 \\
\hline \multicolumn{13}{|c|}{ Body Mass Index (ref. without excess body weight) } \\
\hline $\begin{array}{l}\text { With excess body } \\
\text { weight }\end{array}$ & 33.4 & 0.060 & -19.8 & 0.227 & -10.4 & 0.283 & 6.3 & 0.308 & -2.5 & 0.790 & 4.0 & 0.841 \\
\hline \multicolumn{13}{|c|}{ Physical activity (ref. Insufficiently active) } \\
\hline Sufficiently active & 2.5 & 0.926 & -7.0 & 0.741 & 48.4 & 0.020 & 5.4 & 0.586 & 28.8 & 0.143 & 94.1 & 0.027 \\
\hline \multicolumn{13}{|l|}{ Older Adults } \\
\hline \multicolumn{13}{|l|}{ Sex (ref. male) } \\
\hline Female & -17.8 & 0.101 & 2.6 & 0.865 & -2.3 & 0.679 & 6.2 & 0.025 & -12.3 & 0.052 & -27.8 & 0.160 \\
\hline
\end{tabular}

Skin color (ref. white and yellow)

\begin{tabular}{|c|c|c|c|c|c|c|c|c|c|c|}
\hline Black and brown & -6.9 & 0.469 & -8.1 & 0.518 & -2.5 & 0.733 & 1.3 & 0.756 & 5.8 & $0.500-20.40 .208$ \\
\hline \multicolumn{11}{|c|}{ Smoking status (ref. non-smoker) } \\
\hline Former smoker & 5.6 & 0.621 & -22.8 & 0.141 & -8.2 & 0.240 & 0.2 & 0.949 & 10.7 & $0.217-19.10 .348$ \\
\hline Current smoker & -1.4 & 0.931 & -7.2 & 0.735 & -14.8 & 0.110 & -2.1 & 0.676 & -1.0 & $0.939-30.60 .245$ \\
\hline
\end{tabular}

Alcohol consumption (ref. non-consumer)

\begin{tabular}{|l|c|c|c|c|c|c|c|c|c|c|c|c|}
\hline Consumer & -4.1 & 0.641 & 3.3 & 0.798 & -4.1 & 0.555 & 8.8 & 0.044 & -8.0 & 0.337 & 7.2 & 0.687 \\
\hline $\begin{array}{l}\text { Household per capita } \\
\text { income (US\$ per month) }\end{array}$ & -0.3 & 0.341 & -1.0 & 0.017 & -0.2 & 0.314 & -0.4 & 0.002 & -0.4 & 0.059 & -2.4 & 0.001 \\
\hline
\end{tabular}

Body Mass Index (ref. without excess body weight)

With excess body weight

Physical activity (ref. Insufficiently active)

\begin{tabular}{l|l|l|l|l|l|l|l|l|l|l|l|l|} 
Sufficiently active & -0.54 & 0.974 & 8.6 & 0.747 & -2.0 & 0.826 & 4.8 & 0.366 & 2.2 & 0.817 & 7.8 & 0.810
\end{tabular}

The values of family income per capita were divided per R\$ 100 (US\$57.8 in 2008). Significant associations are indicated in bold. All the models were adjusted for misreporting. 


\section{DISCUSSION}

In the present study, the consumption of SSB was elevated among all age groups, particularly among adolescents. Similar or even smaller portions of SSB have been associated with the development of excess body weight, type 2 diabetes mellitus, and metabolic syndrome in previous studies ${ }^{29-31}$. Sugar-sweetened soda and sweetened coffee and tea represented the beverages with the greatest total energy intake. Our analysis demonstrated that SSB intake was associated with different demographic, socioeconomic, and lifestyle factors, according to life stage and group of SSB.

Adolescents had the highest SSB consumption, representing $14.5 \%$ of total daily energy intake. Data from a national survey evaluating beverages consumption showed that the overall contribution of beverages to total daily energy intake decreased with age ${ }^{9}$. A cross-sectional study involving Mexican adolescents found that SSB consumption contributed to $16.8 \%$ of total daily energy intake ${ }^{32}$. Corroborating these findings, data derived from 187 countries, involving individuals aged $\geq 20$ years, indicated that global SSB consumption was higher in younger adults ${ }^{6}$. However, it is not clear whether this elevated intake among younger subjects is an effect of aging or if recent generations consume more than the older ones ${ }^{2}$.

Sugar-sweetened soda was one of the most consumed beverages, particularly among adolescents. Nationally, a previous study showed that individuals at younger ages, 10 to 39 years, consumed a higher proportion of energy from soft drinks than older ages ${ }^{9}$. Many factors may be associated with a higher SSB intake among adolescents: practical to consume, increase in portion size, and low $\operatorname{cost}^{33-35}$. Stuckler et al. observed that there is a rapid increase in the consumption of sugar-sweetened soda and processed foods in low- and middle-income countries, compared to high-income countries ${ }^{36}$. The advertisement of SSB aimed at children and adolescents has increased in these countries, influencing food preferences, purchase requests, and dietary patterns, as young persons are unable to understand the persuasive intent of sale of these products ${ }^{37}$.

For the most of the SSB, female sex was associated with lower SSB intake. Similar results were also observed in several countries ${ }^{6,29,38}$. A possible explanation for the different consumption according to sex is that female subjects generally require a lower energy intake than male subjects, due to smaller average body weight and lower resting metabolic rate ${ }^{39}$. Other reasons include an increased concern with appearance and a greater health consciousness ${ }^{40,41}$.

The association between household income and SSB presented varied patterns. In older adults and adolescents, household per capita income was negatively associated with the intake sweetened coffee and tea. A previous study with a national representative sample of Brazil also found that individuals with higher income had decreased sweetened coffee intake 9 . In older adults, the mean intake of sweetened fruit juices and total SSB was negatively associated with household per capita income, while in adolescents' age group, income was negatively associated with the intake of sweetened fruit drink, and positively associated with the intake of sweetened fruit juice. The association between low socioeconomic status and higher SSB consumption was seen in a cross-sectional study of the population 
$\geq 2$ years old in the United States ${ }^{42}$. Different factors may explain this association, in general, foods with poor nutritional value cost less per calorie and tend to be selected by groups of lower socioeconomic status ${ }^{43}$. Moreover, individuals of a higher socioeconomic level have additional nutritional knowledge and information about prevention in nutrition, and favor the choice of healthy foods ${ }^{43}$.

In the present study, sufficiently active adults had higher intake of sweetened milk and dairy products compared to insufficient active adults, while adult's former and current smokers presented lower intake of sweetened milk and dairy products when compared to non-smokers. Dairy products have been associated with lower risk of major causes of cardiovascular diseases, and total mortality in a cohort study of individuals aged 35-70 years from 21 countries and are considered a healthy food item in many dietary indexes ${ }^{44-46}$. From this perspective, the intake dairy consumption, even with added sugar, may represent a marker of healthy lifestyle habit.

Excess body weight was associated with higher sugar-sweetened soda intake and total SSB intake among adolescents, and these results were also seen in adolescents from different countries ${ }^{47,48}$. Studies have indicated a lower satiety effect with carbohydrate intake from liquids when compared to carbohydrate intake from solids, resulting in an increased daily energy intake and, consequently, increased susceptibility to obesity ${ }^{12,49}$.

Besides obesity, SSB intake is associated with cardiovascular disease and type 2 diabetes ${ }^{1}$. Systematic review of cohort studies suggested that no intake of SSB would be the optimal intake level for reducing cardiometabolic diseases ${ }^{1}$.

In addition to health adverse effects, Lieffers et al. observed that excess intakes of SSB had \$ 382.8 million direct health care costs and \$ 480.4 million indirect costs in Canada. Altogether, the evidences point to the impact of food choices in the economic burden of cardiometabolic diseases and the importance of reducing the consumption of SSB at the population level to reduce health costs as well as to prevent cardiometabolic diseases ${ }^{50}$.

Some limitations of the present study should be considered. This is a cross-sectional study, and, therefore, we cannot determine causality between the factors evaluated and SSB intake. The $24 \mathrm{HR}$ is a source of errors for the estimation of dietary intake, specifically recall errors, omissions, and errors in portion size estimation. However, in order to minimize bias, dietary data were collected by trained interviewers using a standardized method, usual intake was estimated by using two 24HR and the Multiple Source method.

A further limitation was the different definition of SSB in other studies also evaluating SSB intake, as this made comparisons between studies challenging. The time lag of the data collection is another limitation, since the data was collected in 2008. However, it does not diminish the findings of this study considering that few researches in national literature investigated the same research question in a population-based study ${ }^{10}$. In addition, this investigation used data from a representative sample of one of the world's largest cities that is an important financial center of South America, and a migrant destination for different parts of Brazil and other countries. 
Planning of public health policies aimed at decreasing SSB consumption is essential to reduce the incidence of cardiometabolic diseases. A number of strategies may contribute to greater awareness of reducing SSB consumption among the population, such as taxation of SSB, food marketing regulation, control of SSB sales in schools, and setting product labelling standards to facilitate the prompt identification of unhealthy foods ${ }^{51,52}$. Our findings may be used to improve targeted public health nutrition policies aimed at decreasing SSB consumption.

\section{CONCLUSION}

Our results indicate that age group, sex, household per capita income, and BMI status were characteristics associated with higher intake of SSB.

\section{ACKNOWLEDGMENTS}

We would like to thank all ISA-Capital staff and the researchers of the Evaluation of Food Consumption Research Group (GAC - Grupo de Pesquisa de Avaliação do Consumo Alimentar).

\section{REFERENCES}

1. Micha R, Shulkin ML, Peñalvo JL, Khatibzadeh $S$, Singh GM, Rao M, et al. Etiologic effects and optimal intakes of foods and nutrients for risk of cardiovascular diseases and diabetes: Systematic reviews and meta-analyses from the Nutrition and Chronic Diseases Expert Group (NutriCoDE). PLoS One 2017; 12(4): e0175149. https: / / doi.org/10.1371/ journal.pone.0175149

2. Singh GM, Micha R, Khatibzadeh S, Lim S, Ezzati M, Mozaffarian D. Estimated global, regional, and national disease burdens related to sugar-sweetened beverage consumption in 2010. Circulation 2015; 132(8): 639-66. https://doi.org/10.1161/ CIRCULATIONAHA.114.010636

3. Ramírez-Vélez R, González-Ruíz K, Correa-Bautista JE, Meneses-Echávez JF, Martínez-Torres J. Diferencias demográficas y socioeconómicas asociadas al consumo de bebidas azucaradas em niños y adolescentes colombianos. Nutr Hosp 2015; 31(6): 2479-86. http: / / dx.doi.org/10.3305/nh.2015.31.6.8986
4. Park S, McGuire LC, Galuska DA. Regional differences in sugar-sweetened beverage intake among US adults. J Acad Nutr Diet 2015; 115(12): 1996-2002. https:/ / doi.org/10.1016/j.jand.2015.06.010

5. Bleich SN, Wolfson JA. Trends in SSBs and snack consumption among children by age, body weight, and race/ ethnicity. Obesity 2015; 23(5): 1039-46. https: / / doi.org/10.1002/oby.21050

6. Singh MG, Micha R, Khatibzadeh S, Shi P, Lim S, Andrews $\mathrm{KG}$, et al. Global, regional, and national consumption of sugar-sweetened beverages, fruit juices, and milk: A systematic assessment of beverage intake in 187 countries. PLoS One [Internet] 2015 [cited 2017 Feb 4]; 10(8): e0124845. Available from: https://www.ncbi.nlm.nih. gov/pmc/articles/PMC4526649/pdf/pone.0124845.pdf

7. Buyken AE, Mela DJ, Dussort P, Johnson IT, Macdonald IA, Stowell JD, et al. Dietary carbohydrates: a review of international recommendations and the methods used to derive them. Eur J Clin Nutr 2018; 72(12): 1625-43. https: / / doi.org/10.1038/s41430-017-0035-4 
8. Fisberg M, Kovalskys I, Gómez G, Rigotti A, Sanabria LYC, García MCY, et al. Total and Added Sugar Intake: Assessment in Eight Latin American Countries. Nutrients 2018; 10(4). pii: E389. https:// doi.org/10.3390/nu10040389

9. Pereira RA, Souza AM, Duffey KJ, Sichieri R, Popkin BM. Beverage consumption in Brazil: results from the first National Dietary Survey. Public Health Nutr 2015; 18(7): 1164-72. https:// doi.org/10.1017/ S1368980014001657

10. Figueiredo N, Maia EG, Silva LESD, Granado FS, Claro RM. Trends in sweetened beverages consumption among adults in the Brazilian capitals, 2007-2016. Public Health Nutr 2018; 12(18): 3307-17. https:/ / doi.org/10.1017/S1368980018002161

11. Olson JS, Hummer RA, Harris KM. Gender and Health Behavior Clustering among U.S. Young Adults. Biodemography Soc Biol 2017; 63(1): 3-20. https: / / doi.org/10.1080/19485565.2016.1 262238

12. Barrio-Lopez MT, Martinez-Gonzalez MA, FernandezMontero A, Beunza JJ, Zazpe I, Bes-Rastrollo M. Prospective study of changes in sugar-sweetened beverage consumption and the incidence of the metabolic syndrome and its components: the SUN cohort. Br J Nutr 2013; 110(9): 1722-31. https: / / doi. org/10.1017/S0007114513000822

13. Jayalath VH, de Souza RJ, Ha V, Mirrahimi A, BlancoMejia S, Di Buono M, et al. Sugar-sweetened beverage consumption and incident hypertension: a systematic review and meta-analysis of prospective cohorts. Am J Clin Nutr 2015; 102(4): 914-21. https: / doi. org/10.3945/ajcn.115.107243

14. Matsudo S, Araújo T, Matsudo V, Andrade D, Andrade E, Oliveira LC, et al. International Physical Activity Questionnaire (IPAQ): Study of validity and reliability in Brazil. Rev Bras Ativ Fís Saúde 2001; 6(2): 5-12. https: / / doi.org/10.12820/ rbafs.v.6n2p5-18

15. De Onis M, Onyango AW, Borghi E, Siyam A, Nishida C, Siekmann J. Development of a WHO growth reference for school-aged children and adolescents. Bull World Health Organ 2007; 85(9): 660-7. https: / / doi.org/10.2471/blt.07.043497

16. World Health Organization. Consultation on Obesity: Preventing and managing the global epidemic. Geneva: World Health Organization; 1998. WHO-Technical Report Series no. 894.

17. Lebrão ML, Duarte YAO. SABE - Saúde, Bem-estar e Envelhecimento - O Projeto Sabe no município de São Paulo: uma abordagem inicial. Brasília: Organização Pan-Americana da Saúde; 2003.
18. Carvalho AM, Piovezan LG, Selem SSC, Fisberg RM, Marchioni DML. Validação e calibração de medidas de peso e altura autorreferidas por indivíduos da cidade de São Paulo. Rev Bras Epidemiol 2014; 17(3): 735-46. http://dx.doi. org/10.1590/1809-4503201400030013

19. Blanton CA, Moshfegh AJ, Baer DJ, Kretsch MJ. The USDA Automated Multiple-Pass Method accurately estimates group total energy and nutrient intake. J Nutr 2006; 136(10): 2594-9. https: / / doi.org/10.1093/ jn/136.10.2594

20. NCC Food and Nutrient Database Version 2007. Regents of the University of Minnesota -NDSR Manual. Nutrition Coordinating Center; 2007.

21. Núcleo de Estudos e Pesquisas em Alimentação. Tabela Brasileira de Composição de Alimentos - TACO. $4^{\text {th }}$ ed. Campinas: NEPA-UNICAMP; 2011.

22. Universidade de São Paulo. Faculdade de Ciências Farmacêuticas. Departamento de Alimentos e Nutrição Experimental. Tabela Brasileira de Composição de Alimentos-USP. Versão 5.0 [Internet]. [cited 2016 Oct.]. Available from: http://www. intranet.fcf.usp.br/tabela/

23. Institute of Medicine of the National Academies. Dietary Reference Intakes for Energy, Carbohydrate, Fibre, Fat, Fatty Acids, Cholesterol, Protein and Amino Acids. Washington, D.C.: National Academies Press; 2002.

24. Subar AF, Freedman LS, Tooze JA, Kirkpatrick SI, Boushey C, Neuhouser ML, et al. Addressing Current Criticism Regarding the Value of Self-Report Dietary Data. J Nutr 2015; 145(12): 2639-45. https:/ / doi. org/10.3945/jn.115.219634

25. Kelly MT, Rennie KL, Wallace JM, Robson PJ, Welch RW, Hannon-Fletcher MP, et al. Associations between the portion sizes of food groups consumed and measures of adiposity in the British National Diet and Nutrition Survey. Br J Nutr 2009; 101(9): 1413-20. https:// doi.org/10.1017/ S0007114508060777

26. Miller PE, McKinnon RA, Krebs-Smith SM, Subar AF, Chriqui J, Kahle L, et al. Sugar-sweetened beverage consumption in the U.S.: novel assessment methodology. Am J Prev Med 2013; 45(4): 416-21. https: / / doi.org/10.1016/j.amepre.2013.05.014

27. German Institute of Human Nutrition PotsdamRehbrücke. Department of Epidemiology. The Multiple Source Method (MSM) [Internet]. German Institute of Human Nutrition Potsdam-Rehbrücke; 2012 [cited 2016 May]. Version 1.0.1. Available from: https://nugo.dife.de/msm 
28. Verly-Jr. E, Castro MA, Fisberg RM, Marchioni DM. Precision of usual food intake estimates according to the percentage of individuals with a second dietary measurement. J Acad Nutr Diet 2012; 112(7): 101520. https: / / doi.org/10.1016/j.jand.2012.03.028

29. Chan TF, Lin WT, Huang HL, Lee CY, Wu PW, Chiu YW, et al. Consumption of sugar-sweetened beverages is associated with components of the metabolic syndrome in adolescents. Nutrients 2014; 6(5): 2088103. https: / / doi.org/10.3390/nu6052088

30. Fagherazzi G, Vilier A, Saes Sartorelli D, Lajous M, Balkau B, Clavel-Chapelon F. Consumption of artificially and sugar-sweetened beverages and incident type 2 diabetes in the Etude Epidèmiologique auprès des femmes de la Mutuelle Gènèrale de l'Education Nationale-European Prospective Investigation into Cancer and Nutrition cohort. Am J Clin Nutr 2013; 97(3): 517-23. https://doi.org/10.3945/ajcn.112.050997

31. Dhingra R, Sullivan L, Jacques PF, Wang TJ, Fox CS, Meigs JB, et al. Soft drink consumption and risk of developing cardiometabolic risk factors and the metabolic syndrome in middle-aged adults in the community. Circulation 2007; 116(5): 480-8. https: / / doi.org/10.1161/CIRCULATIONAHA.107.689935

32. Stern D, Piernas C, Barquera S, Rivera JA, Popkin BM. Caloric beverages were major sources of energy among children and adults in Mexico, 1999-2012. J Nutr 2014; 144(6): 949-56. https:/ / doi.org/10.3945/ jn.114.190652

33. Ebbeling CB, Pawlak DB, Ludwig DS. Childhood obesity: public-health crisis, common sense cure. Lancet 2002; 360(9331): 473-82. https:// doi.org/10.1016/ S0140-6736(02)09678-2

34. Nielsen SJ, Popkin BM. Changes in beverage intake between 1977 and 2001. Am J Prev Med 2004; 27(3): 205-10. https:// doi.org/10.1016/j.amepre.2004.05.005

35. Watters CA, Corrado RS, Chaloupka FJ. Prices of healthy and unhealthy beverages in high and low per capita income areas. Hawaii J Med Public Health 2013; 72(3): 76-9.

36. Stuckler D, McKee M, Ebrahim S, Basu S. Manufacturing epidemics: The role of global producers in increased consumption of unhealthy commodities including processed foods, alcohol, and tobacco. PLoS One [Internet] 2012 [cited 2017 Feb. 4]; 9(6): e1001235. Available from: https://www.ncbi.nlm.nih.gov/pmc/ articles/PMC3383750/pdf/pmed.1001235.pdf

37. Organização Pan-Americana da Saúde. Recommendations from a Pan American Health Organization Expert Consultation on the Marketing of Food and Non-Alcoholic Beverages to Children in the Americas. Washington, D.C.: PAHO; 2011.
38. Vereecken CA, Inchley J, Subramanian SV, Hublet A, Maes L. The relative influence of individual and contextual socio-economic status on consumption of fruit and soft drinks among adolescents in Europe. Eur J Public Health 2005; 15(3): 224-32. https: / / doi. org/10.1093/eurpub/cki005

39. Rolls BJ, Fedoroff IC, Guthrie JF. Gender differences in eating behavior and body weight regulation. Health Psychol 1991; 10(2): 133-42. https://doi. org/10.1037/ / 0278-6133.10.2.133

40. Nathanson CA. Sex roles as variables in preventive health behavior. J Community Health 1977; 3(2): 14255. https:// doi.org/10.1007/bf01674236

41. Roos E, Lahelma E, Virtanen M, Prättälä R, Pietinen P. Gender, socioeconomic status and family status as determinants of food behaviour. Soc Sci Med 1998; 46(12): 1519-29. https://doi.org/10.1016/ s0277-9536(98)00032-x

42. Han E, Powell LM. Consumption patterns of sugar sweetened beverages in the United States. J Acad Nutr Diet 2013; 113(1): 43-53. https:// doi.org/10.1016/j. jand.2012.09.016

43. Darmon N, Drewnowski A. Contribution of food prices and diet cost to socioeconomic disparities in diet quality and health: a systematic review and analysis. Nutr Rev 2015; 73(10): 643-60. https: / / doi. org/10.1093/nutrit/nuv027

44. Dehghan M, Mente A, Rangarajan S, Sheridan P, Mohan V, Iqbal R, et al. Association of dairy intake with cardiovascular disease and mortality in 21 countries from five continents (PURE): a prospective cohort study. Lancet 2018; 392(10161): 2288-97. https: / / doi. org/10.1016/S0140-6736(18)31812-9

45. Krebs-Smith SM, Pannucci TE, Subar AF, Kirkpatrick SI, Lerman JL, Tooze JA, et al. Update of the Healthy Eating Index: HEI-2015. J Acad Nutr Diet 2018; 118(9): 1591-602. https:// doi.org/10.1016/j.jand.2018.05.021

46. Previdelli AN, Andrade SC, Pires MM, Ferreira SR, Fisberg RM, Marchioni DM. A revised version of the Healthy Eating Index for the Brazilian population. Rev Saúde Pública 2011; 45(4): 794-8. https:/ / doi. org/10.1590/s0034-89102011005000035

47. Albar SA, Alwan NA, Evans CEL, Cade J. Is there an association between food portion size and BMI among British adolescents? Br J Nutr 2014; 112(5): 841-51. https: / doi.org/10.1017/S0007114514001548

48. Martin-Calvo N, Martínez-González MA, Bes-Rastrollo M, Gea A, Ochoa MC, Marti A. Sugar-sweetened carbonated beverage consumption and childhood/ adolescent obesity: a case-control study. Public Health Nutr 2014; 17(10): 2185-93. https: / / doi.org/10.1017/ S136898001300356X 
49. Pan A, Hu FB. Effects of carbohydrates on satiety: Differences between liquid and solid food. Curr Opin Clin Nutr Metab Care 2011; 14(4): 385-90. https: / / doi. org/10.1097/ MCO.0b013e328346df36

50. Lieffers JRL, Ekwaru JP, Ohinmaa A, Veugelers PJ. The economic burden of not meeting food recommendations in Canada: The cost of doing nothing. PLoS One 2018; 13(4): e0196333. https:/ / doi.org/10.1371/journal.pone.0196333

51. Studdert DM, Flanders J, Mello MM. Searching for public health law's sweet spot: The regulation of sugar-sweetened beverages. PLoS One [Internet] 2015 [cited 2017 Feb. 4]; 12(7). Available from: https:/ /www.ncbi.nlm.nih.gov/ pmc/articles/PMC4494810/pdf/pmed.1001848.pdp https: / / doi.org/10.1371/journal. pmed.1001848

52. World Health Organization. Plan of Action for the Prevention of Obesity in Children and Adolescents. Washington, D.C.: World Health Organization; 2014.
Received on: 10/18/2018

Revised on: 11/30/2018

Accepted on: 11/30/2018

Authors' contribution: ASF contributed with analysis, interpretation of data and wrote the manuscript. ACP, DASV and MMF contributed with analysis, interpretation of data and critically revising it for important intellectual content. CLGC, MCGPA, MG e DMM were involved in the conception and design of the study and in critically revising the manuscript for important intellectual content. RMF was involved in the conception and design of the study, data interpretation, and critically revising the manuscript for important intellectual content. All authors read and approved the submitted version. 